\title{
PRIRODNA NALAZIŠTA TARTUFA U HRVATSKOJ I EKOLOŠKI PROBLEMI NJIHOVOG RAZVOJA
}

\section{TRUFFLES IN CROATIA: NATURAL DISTRIBUTION AND ECOLOGICAL PROBLEMS}

\author{
Ivica TIKVIĆ ${ }^{\text {, Damir UGARKOVIĆ }}$, Željko ZEČIĆ2 ${ }^{\text {, Patrik KORIJAN }}$, Davor GAŠPAR ${ }^{4}$
}

\begin{abstract}
Sažetak
Tartufi su prirodne simbiotske gljive na šumskom drveću, koji se razvijaju u većini šumskih ekosustava Hrvatske. Posebna pozornost im se posvećuje zbog gastronomski vrlo traženog i skupog plodišta. Tartufi u Hrvatskoj se najintezivnije sakupljaju u šumama u Istri, iako je poznato da se plodišta tih gljiva razvijaju i u ostalim područjima primorske i kontinentalne Hrvatske sve do 600 m nadmorske visine. U radu su prikazana nova nalazišta tartufa u Hrvatskoj, kao i podaci o rasprostranjenosti tartufa u Europi. Gospodarenje tartufima u šumskim ekosustavima Hrvatske nije potpuno organizirano. Glavni problemi potrajnog gospodarenja tartufima u šumama su promjena ekoloških uvjeta, intenzivno i neorganizirano sakupljanje, kao i smanjenje vitalnosti stabala. U radu su prikazani najvažniji nepovoljni ekološki i drugi čimbenici za razvoj tartufa. Prikazane su mogućnosti unaprjeđenja proizvodnje tartufa u šumama i u plantažama tartufa, s posebnim naglaskom na gospodarenje staništem.
\end{abstract}

KLJUČNE RIJEČI: tartufi, nalazišta tartufa, staništa tartufa, ekološki problemi, potrajno gospodarenje tartufima

\section{UVOD}

\section{INTRODUCTION}

Tartufi su prirodni šumski organizmi koji ovise o rastu i razvoju šumskog drveća. Oni su najvažnije gljive u šumskim ekosustavima jer uspostavljaju mutualističku simbiozu. To je obostrano koristan suživot gljiva sa šumskim drvećem i drugim biljkama koji se naziva mikoriza, jer se razvija na korijenju (od grčkih riječi mykes - gljiva, rhiza - korijen). Mikoriza je najzastupljeniji oblik simbioze na šumskom drveću i utvrđena je na preko 8000 biljnih simbionata (Smith i Read, 1997). Većina gospodarskih vrsta drveća u Hrvatskoj tvore ektomikorizu. Korijenje šumskog drveća i mikoriza najintenzivnije se razvijaju u površinskim slojevima tla.
Prema Souch i suradnicima (2004) najintenzivniji razvoj korijenja šumskog drveća je do $30 \mathrm{~cm}$ dubine tla, dok se prema Wilpertu i Schäfferu (2006) oko 45\% sitnog korijenja šumskog drveća razvija do $10 \mathrm{~cm}$ dubine tla. Značaj simbioze očituje se u prijenosu organskih tvari od biljke prema gljivi, kao i prijenosu anorganskih tvari i vode od gljive prema biljci. Ta izmjena tvari između simbionata je neophodna za njihov život (Smith i Read, 1997).

Tartufi su hipogejne gljive koje razvijaju svoja vegetativna tkiva i plodišta na različitim dubinama u tlu (Hall i sur., 2007). Upravo zbog toga što se cijeli život razvijaju u tlu i nisu vidljivi, prirodna rasprostranjenost tartufa još uvijek je dosta nepoznata.

\footnotetext{
${ }_{1}^{1}$ Prof. dr. sc. Ivica Tikvić, ivica.tikvic@zg.htnet.hr, Sveučilište u Zagrebu Šumarski fakultet, Zavod za ekologiju i uzgajanje šuma, Svetošimunska 25, 10002 Zagreb, Hrvatska ${ }^{1}$ Doc. dr. sc. Damir Ugarković, damir.urgarkovic@gs.htnet.hr,

2 Prof. dr. sc. Željko Zečić, zzecic@hrast.sumfak.hr, Sveučilište u Zagrebu Šumarski fakultet, Zavod za šumarske tehnike i tehnologije, Svetošimunska 25, 10002 Zagreb, Hrvatska

${ }^{3}$ Patrik Korijant, mag. ing. silv., Ročko polje 42, Buzet, Hrvatska

${ }^{4}$ Davor Gašpar, dipl. ing. šum, davor.gaspar@sb.t-com.hr, Lea Müllera 65, 10000 Zagreb, Hrvatska
} 
a)

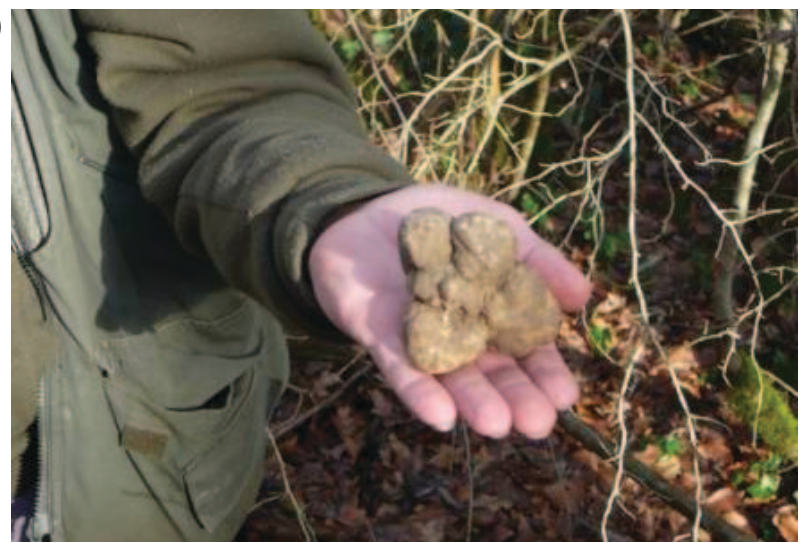

b)

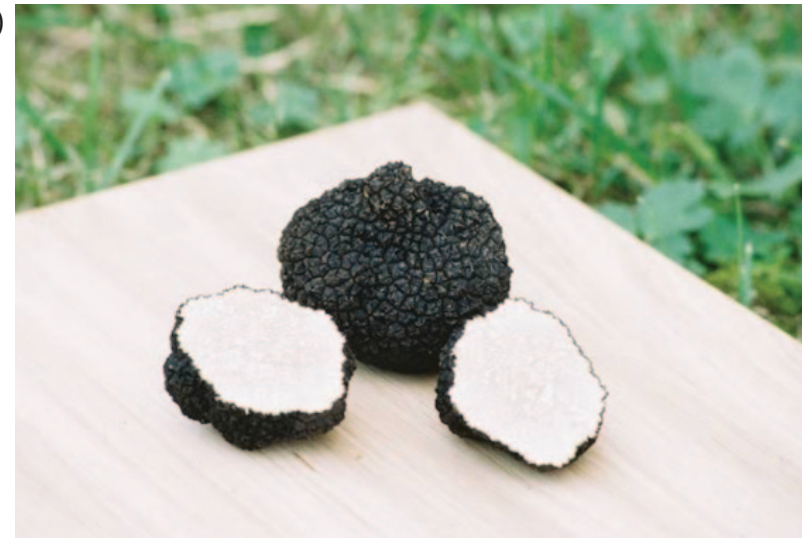

Slika 1 Plodišta velikog bijelog tartufa (Tuber magnatum Pico a) i ljetnog tartufa (Tuber aestivum Vittadini) iz Posavine (b) Figure 1 White truffle Tuber magnatum Pico (a) and summer truffle Tuber aestivum Vittadini from Posavina region in Croatia (b)

Hrvatska je potencijalno bogata tatrufima, jer se na oko $40 \%$ kopnenog dijela Hrvatske obraslog šumama oni mogu razvijati od nizinskih do brdskih područja (Frančišović, 1950). Šumska staništa tartufa u Hrvatskoj su vrlo povoljna (Tikvić i sur., 2012). Pokazatelj toga je intenzivni rast šumske vegetacije, kao i najveći primjerak velikog bijelog tartufa u svijetu, koji je pronašao Giancarlo Zigante u Motovunskoj šumi u Istri. Taj je primjerak bio je težak 1,3 kg i on je 1999. godine upisan u Guinnessovu knjigu svjetskih rekorda.

Šumsko drveće je glavni simbiont tartufa. Općenito najvažniji simbionti tartufa su hrastovi lužnjak, kitnjak, medunac i dr. vrste. Veliki bijeli tartuf (Tuber magnatum Pico) tvori mikorizu s hrastom lužnjakom (Quercus robur L.), velelisnom lipom (Tilia platyphyllos Scop.), crnom topolom (Populus nigra L.), trepetljikom (Populus tremula L.), bijelom topolom (Populus alba L.), bijelom vrbom (Salix alba L.), košarastom vrbom (Salix viminalis L.) i vrbom ivom (Salix caprea L.). Crni tamnosporni tartuf (Tuber melanosporum Vittadini) tvori mikorizu sa hrastom meduncem (Quercus pubescens Willd.), crnim grabom (Ostrya carpinifolia Scop.), lijeskom (Corylus avellana L.), alepskim borom (Pinus halepensis Mill.), običnim borom (Pinus sylvestris L.) i pinijom (Pinus pinea L.). Prema Hrki (1984) hrast cer (Quercus cerris L.) i obična bukva (Fagus sylvatica L.) su također simbionti bijelih i crnih tartufa.

Tartufi kao i druge gljive imaju vegetativna tkiva koja se sastoje od spletova tankih i vrlo sitnih hifa, koje se razvijaju na korijenu biljaka i u tlu. Razvoj vegetativnih tkiva i plodišta tartufa ovisi o simbiozi s drvećem i o uvjetima u staništu (Arnolds, 1991). Kada je tlo odgovarajućeg sastava i ima dovoljno vlage, kada je povoljna temperatura tla i kada je biljka simbiont dobre vitalnosti, tartufi se optimalno razvijaju i plodonose. Ako se jedan od tih čimbenika poremeti, dolazi do smanjenja rasta micelija i njihovog vegetiranja te izostanka razvoja plodišta (Hrka, 1988).Oštećenja šumskog tla i korijenja šumskog drveća mehanizacijom, divljim i domaćim životinjama i djelovanjem čovjeka, kao i promjene stanišnih uvjeta u šumama, izazivaju oštećenja vrlo sitnih i osjetljivih spletova hifa, što rezultira slabijim rastom vegetativnih tkiva, slabom fruktifikacijom tartufa i smanjenjem rasta stabala (Tikvić i sur., 2012).

U svijetu je opisano preko 180 vrsta tartufa (Bonito i sur., 2013), a u Hrvatskoj se pojavljuje nekoliko desetaka vrsta (Božac, 2008), iako točan broj vrsta nije utvrđen. Vrste tartufa se razlikuju prema boji plodišta, obilježjima površine kožice plodišta, boji i nervaturi unutarnjeg tkiva plodišta te obliku i veličini spora. Tartufi se općenito dijele prema boji plodišta na bijele i crne. Najpoznatije vrste bijelih tartufa su: Tuber magnatum Pico - bijeli tartuf (slika 1a), Tuber borchii Vittadini - borhijev tartuf, Tuber albinum Pico ožujski tartuf, Tuber maculatum Vittadini - pjegavi tartuf, Tuber excavatum Vittadini - izdubljeni tartuf, Tuber nitidum Vittadini, Tuber ferrugineum, Tuber oligosporum Vittadini, Tuber rufum Pico - crvenkasti tartuf i Tuber asa.

Najpoznatije vrste crnih tartufa su: Tuber melanosporum Vittadini - crni tamnosporni tartuf, Tuber aestivum Vittadini - ljetni tartuf (slika 1b), Tuber brumale Vittadini - zimski tartuf, Tuber macrosporum Vittadini - golemosporni tartuf, Tuber mesentericum Vittadini - crijevoliki tartuf, Tuber uncinatum Chatin, Tuber hiemalbum i Tuber melanconii.

Prema pravilniku o zaštiti gljiva (2002) u Hrvatskoj je 12 vrsta tartufa koje se mogu koristiti u komercijalne svrhe. Četiri su vrste bijelih tartufa (Tuber asa, T. borchii, T. maculatum i T. magnatum) i osam vrsta crnih tartufa (T. aestivum, T. brumale, T. hiemalbum, T. macrosporum, T. malenconii, T. melanosporum, T. mesentericum i T. uncinatum).

Tartufi se prirodno razvijaju u različitim područjima svijeta, od umjereno toplih područja do pustinjskih područja Europe, Azije, Amerike, Afrike i Australije (Hall i sur., 2007). Oni su vertikalno rasprostranjeni od nizinskih do brdskih područja. Tartufi su u Europi prirodno rasprostranjeni u velikom broju zemalja (slike $4,5 \mathrm{i} 6$ ), iako se pojedine vrste razvijaju u točno određenim ekološkim uvjetima. Jedna od 


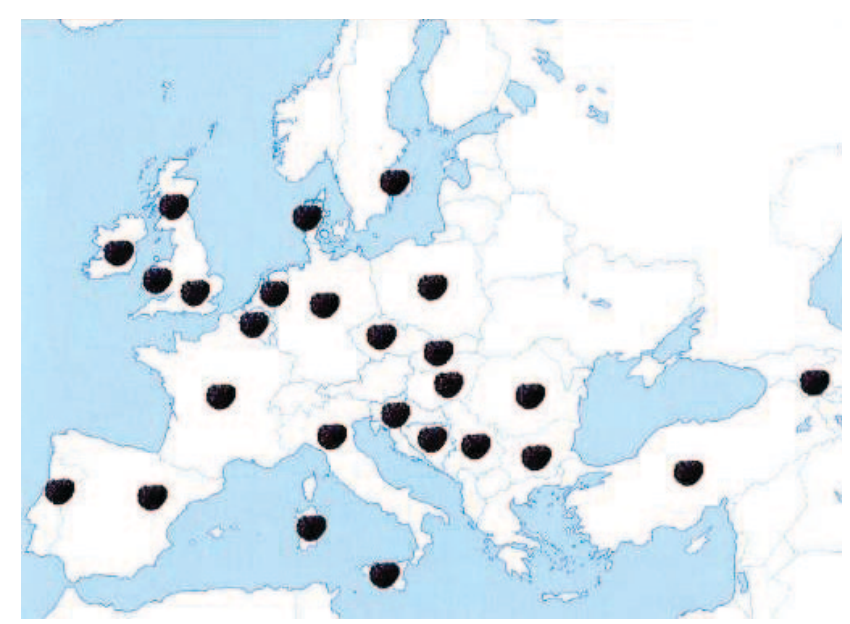

Slika 2 Rasprostranjenost ljetnog tartufa T. aestivum Vittadini u Europi i Maloj Aziji (izvor: Hall i sur., 2007)

Figure 2 Distribution of summer truffle T. aestivum Vittadini in Europe and Asia (source: Hall et al., 2007)

najraširenijih vrsta tartufa u Europi je Tuber aestivum Vittadini, koja se razvija od Sicilije do južnih dijelova Skandinavije, te od Portugala i Irske na zapadu do Poljske, Rumunjske i Turske na istoku (slika 2).

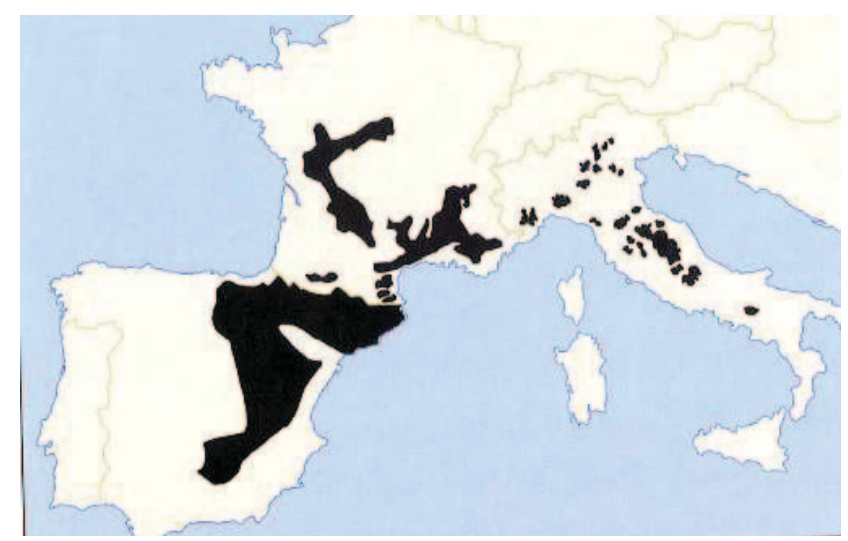

Slika 3 Rasprostranjenost crnog tamnospornog tartufa Tuber melanosporum Vittadini u Španjolskoj, Francuskoj i Italiji (izvor: Hall i sur., 2007)

Figure 3 Distribution of Tuber melanosporum Wittadini in Spain, France and Italy (source: Hall et al., 2007)

Crni tamnosporni tartuf Tuber melanosporum Vittadini je značajnije zastupljen u jugozapadnom dijelu Europe (Španjolska, južna i zapadna Francuska te sjeverna i središnja Italija (slika 3).

Borchijev tatruf Tuber borchii Vittadini je jedna od najrasprostranjenijih vrsta bijelih tartufa. Razvija se od Španjolske i Irske na zapadu do Finske, Poljske i Rumunjske na istoku (slika 4).

Tartufi su u Hrvatskoj prvi put pronađeni 1929. godine u šumama Istre, dok su kasnije pronađeni i u drugim dijelovima Hrvatske (Zgrablić i sur., 2014). Međutim još uvijek

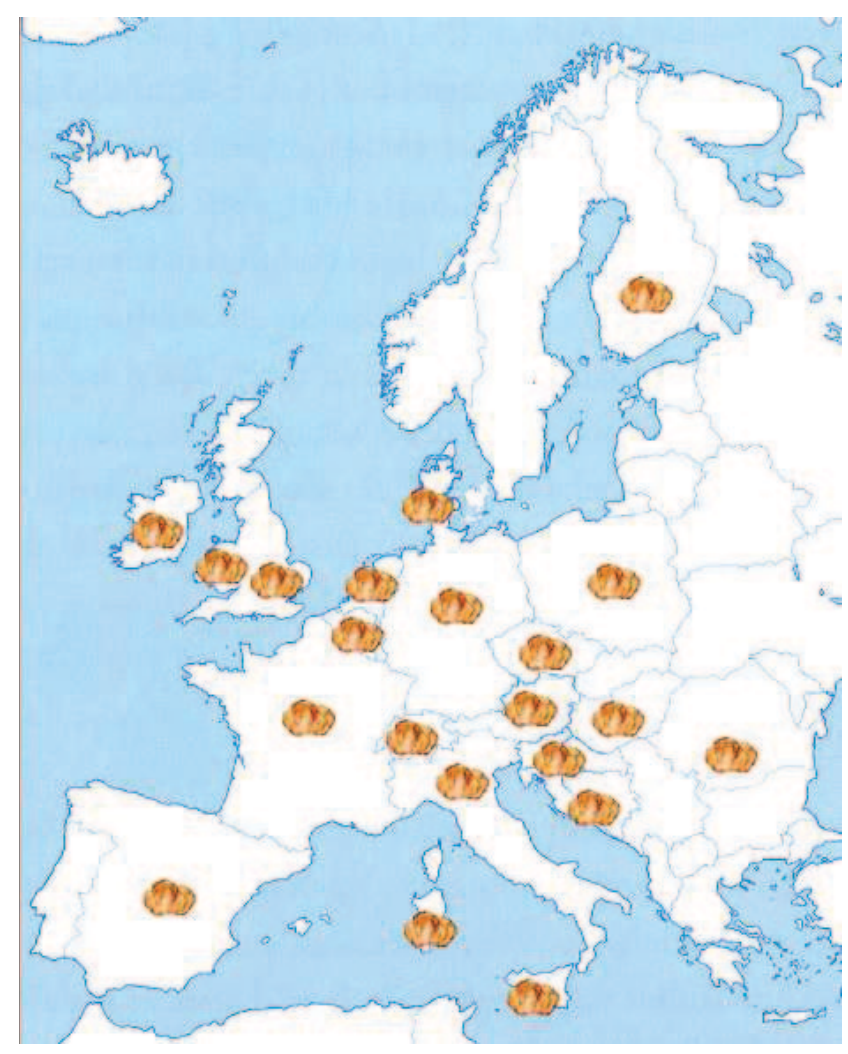

Slika 4 Rasprostranjenost borchijevog tartufa Tuber brochii Vittadini u Europi (izvor: Hall i sur. 2007)

Figure 4 Distribution of Tuber brochii in Europe (source: Hall et al., 2007)

je nepoznato gdje se sve tartufi prirodno razvijaju u Hrvatskoj, jer je o tome bilo malo istraživanja. Cilj ovoga rada je bio prikazati rezultate recentnih istraživanja rasprostranjenosti tartufa u Hrvatskoj i glavne ekološke probleme za razvoj tartufa u šumskim ekosustavima.

\section{PODRUČJE ISTRAŽIVANJA I METODE RADA RESEARCH AREA AND METHODS}

U sklopu projekta „Smjernice za povećanje proizvodnje tartufa na privatnim šumo-posjedima u Republici Hrvatskoj"

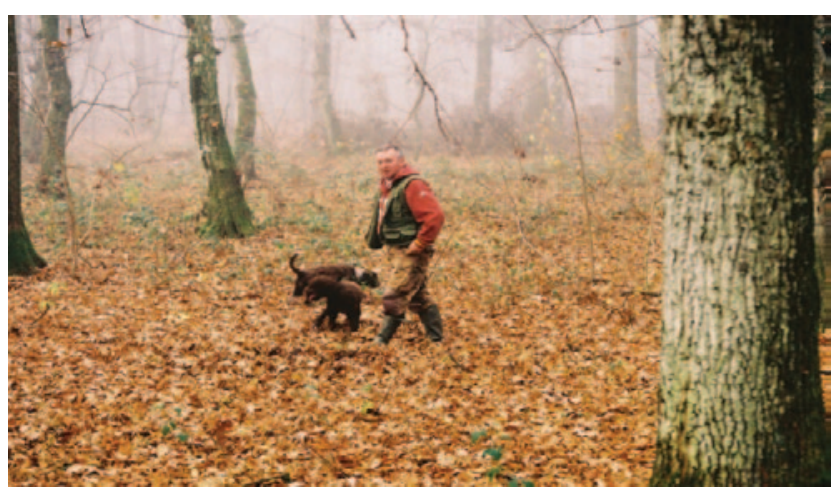

Slika 5 Profesionalni tarufar sa tartufarskim psima pasmine Lagotto Romagnolo

Figure 5 Truffle hunter with truffle dogs Lagotto Romagnolo 
a)

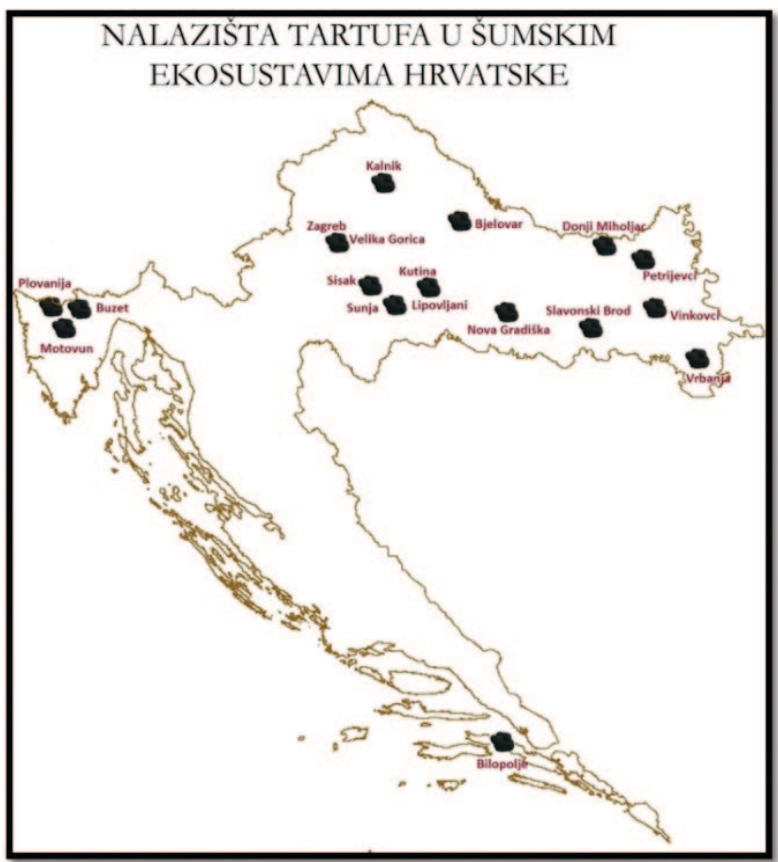

b)

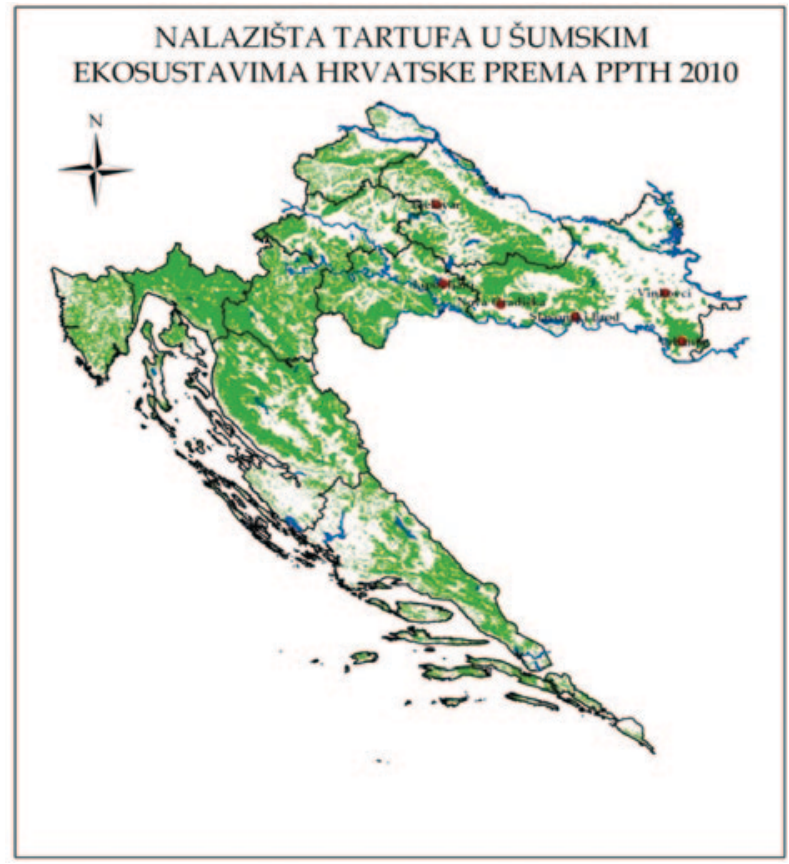

Slika 6 Nalazišta tartufa u Hrvatskoj prema literaturi (a) i nova nalazišta tartufa u Posavini i sjeverozapadnoj Hrvatskoj (crvene oznake) Figure 6 Truffle localities in Croatia according to literature (a) and new truffle localities in Posavina and north-west Croatia (b, red lebels)

provedeno je istraživanje prirodne rasprostranjenosti tartufa u šumama Posavine i sjeverozapadne Hrvatske, u su-
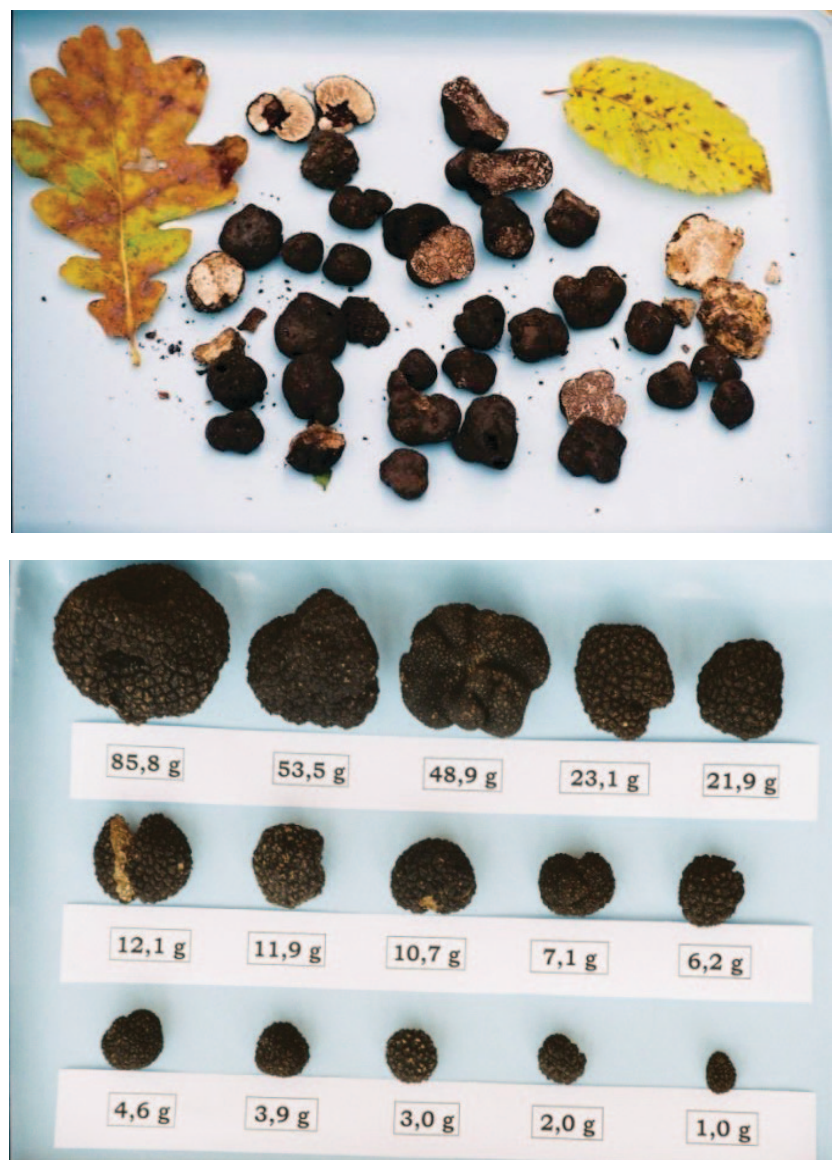

radnji sa profesionalnim tartufarima koji su koristili tartufarske pse pasmine Lagotto Romagnolo za traženje tartufa
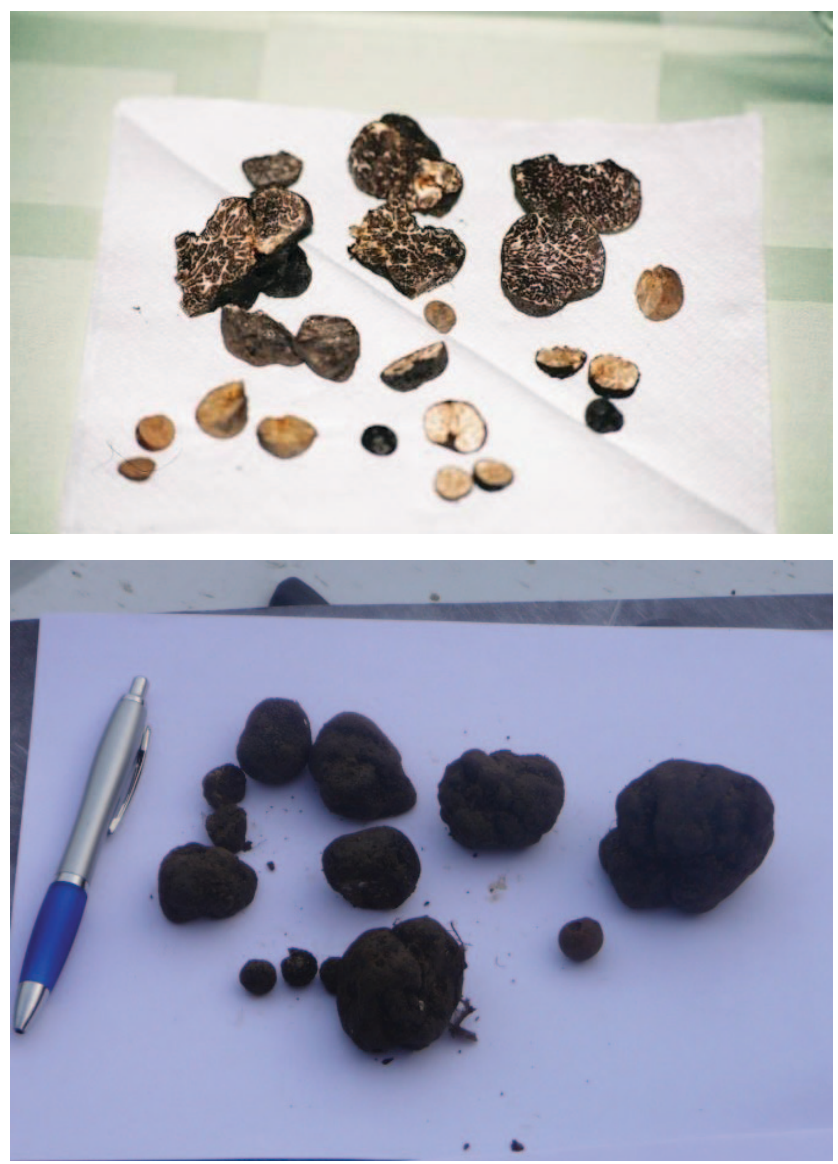

Slika 7 Uzorci crnih i bijelih tartufa pronađeni u istraživanjima tartufa u Posavini 2010. godine

Figure 7 Black and white truffle specimens found in truffle research in Posavina 2010 
(slika 5). Istraživanje je provedeno u nizinskim i brežuljkastim šumama tih područja. Analiza obilježja mikoriznog korijenja iz tih nalazišta napravljena je u ekološkom laboratoriju Zavoda za ekologiju i uzgajanje šuma na Šumarskom fakultetu Sveučilišta u Zagrebu i u laboratoriju INA d.d. Zagreb.

\section{REZULTATI RESULTS}

\section{Prirodna rasprostranjenost tartufa u Hrvatskoj - Natural distribution of truffles in Croatia}

Prema dostupnoj literaturi poznato je da su tartufi u Hrvatskoj rasprostranjeni u kontinentalnom i primorskom području. U prošlosti tartufi su bili pronađeni u Motovunskoj šumi, u šumama oko Buzeta, Plovanije, Zagreba, Velike Gorice, na Kalniku, oko Siska, Sunje, Kutine, Lipovljana, Do-

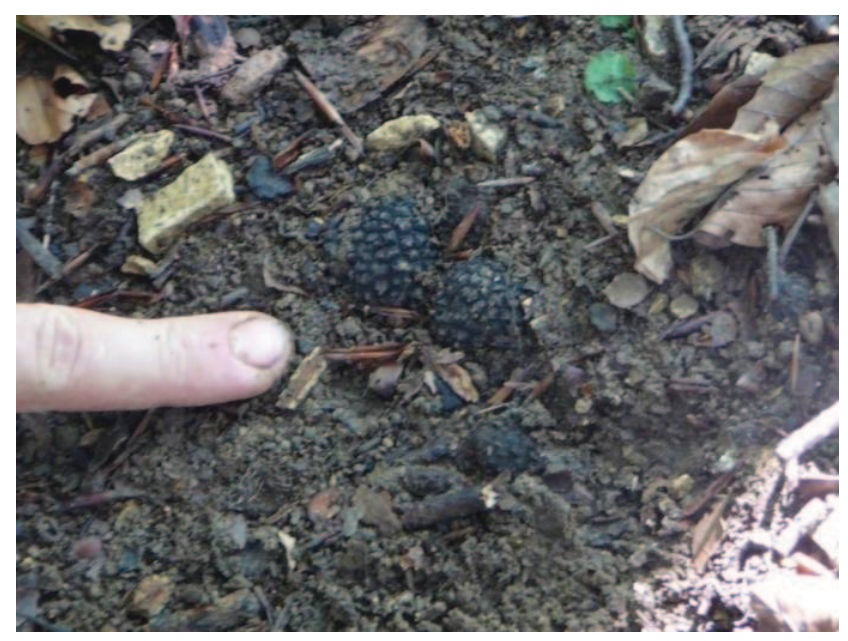

Slika 8 Plodišta crnog ljetnog tartufa Tuber aestivum Vittadini pronađena pri samoj površini šumskog tla

Figure 8 Black summer truffle Tuber aestivum Vittadini found at the surface of forest soil

a)

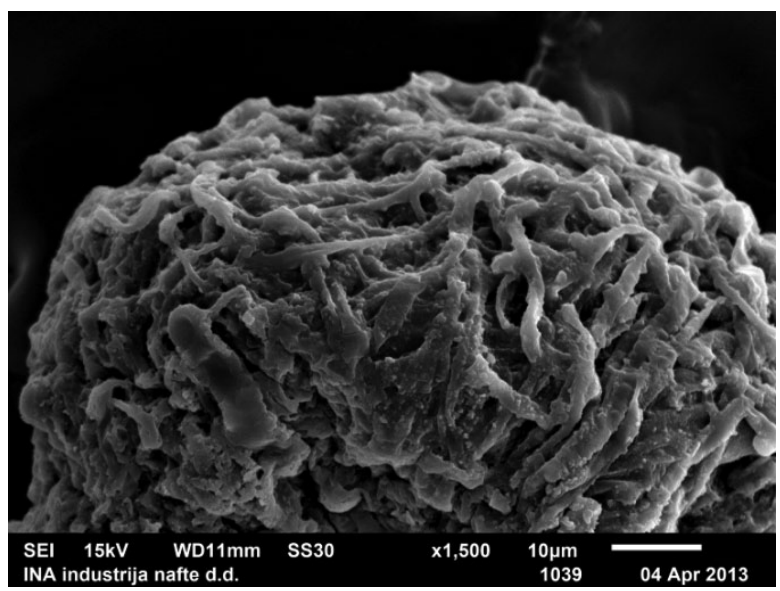

njeg Miholjca, Petrijevaca i na poluotoku Pelješcu oko Bilopolja (slika 6a). U istraživanjima tartufa u Posavini i sjeverozapadnoj Hrvatskoj pronađena su plodišta tartufa na svim lokacijama na kojima je vršeno traženje tartufa.

Nova nalazišta tartufa koja su utvrđena bila su u šumama oko Bjelovara, Lipovljana, Nove Gradiške, Slavonskog Broda, Vinkovaca i Vrbanje (slika 6b). Na svim lokalitetima na kojima su pronađeni tartufi utvrđena su plodišta nekoliko različitih vrsta tatrufa (slike 7 i 8).

\section{Ekološki problemi u staništima tartufa u Hrvatskoj - Ecological problems in truffle habitats in Croatia}

Razvoj šumskog drveća značajno ovisi o djelovanju ekoloških i bioloških čimbenika, koji utječu na fiziološke procese u drveću. Jedan od najvažnijih fizioloških procesa za šumsko drveće, pa i mikorizu, je upijanje hranjiva iz šumskog tla. Ono se ostvaruje pomoću korijenja šumskog drveća, ali značajnu ulogu u tom procesu imaju i mikroorganizmi, posebno simbiotski mikroorganizmi kao što su tartufi. Korijenje šumskog drveća i mikroorganizmi u površinskim slojevima tla su značajno utjecani brojnim nepovoljnim čimbenicima. Šumsko tlo predstavlja najvažniji dio šumskih staništa, iako i drugi ekološki čimbenici mogu imati značajnu ulogu za razvoj mikroorganizama, kao što su klima, reljef i voda (Bragato i sur., 2004). U šumama se pojavljuju sve veći poremećaji biološke i ekološke ravnoteže (štetnici, promjena prirodnosti zajednica, vremenske nepogode, onečišćenje zraka, vode i tla, promjene prirodnih ekoloških čimbenika i dr.). Svi ti čimbenici nepovoljno utječu na stanje stabala pa time i na stanje simbioze na korijenu šumskog drveća.

Najvažniji nepovoljni čimbenici za šumsko drveće i za tartufe su ekološki (vremenske nepogode, suša, mraz, poplave, oluje, tuča) i biološki (kukci, biljne bolesti, divljač, domaće životinje i antropogeni utjecaji). Antropogeni utjecaji dovode do promjene prirodnosti šumskih zajednica, promjene

b)

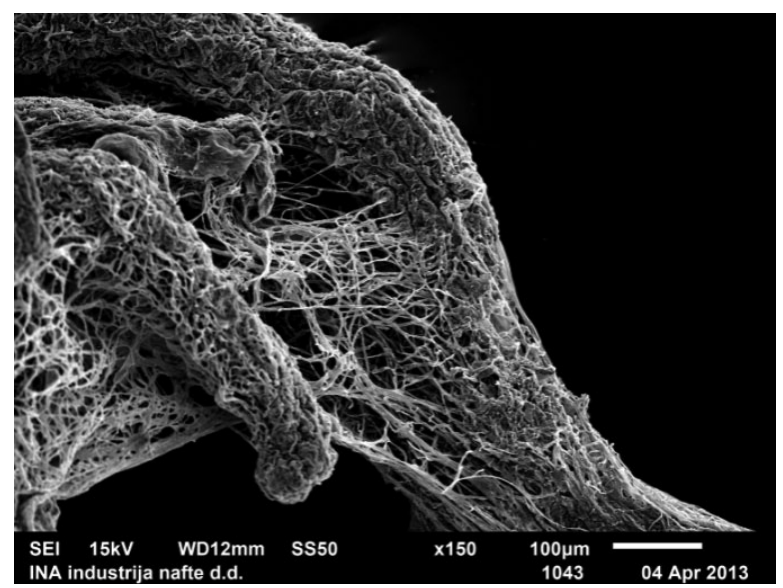

Slika 9 Splet hifa ektomikorize na jednom korjenovom vrhu (a, povećanje 1500x) i splet micelija na korijenju hrasta lužnjaka (b, povećanje 150x). Figure 9. Ectomycorrhiza hyphae tissue on root tip (a, magnification 1500x) and mycelial tissue on pedunculate oak root (b, magnification 150x) 
a)

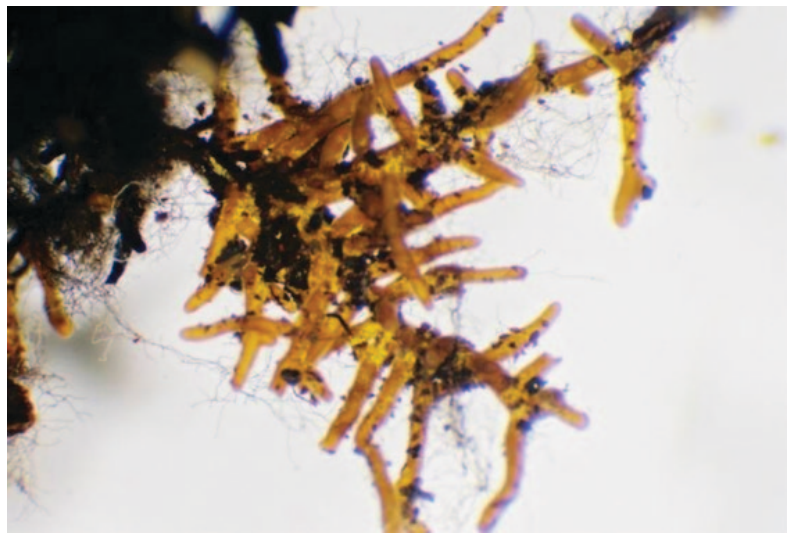

b)

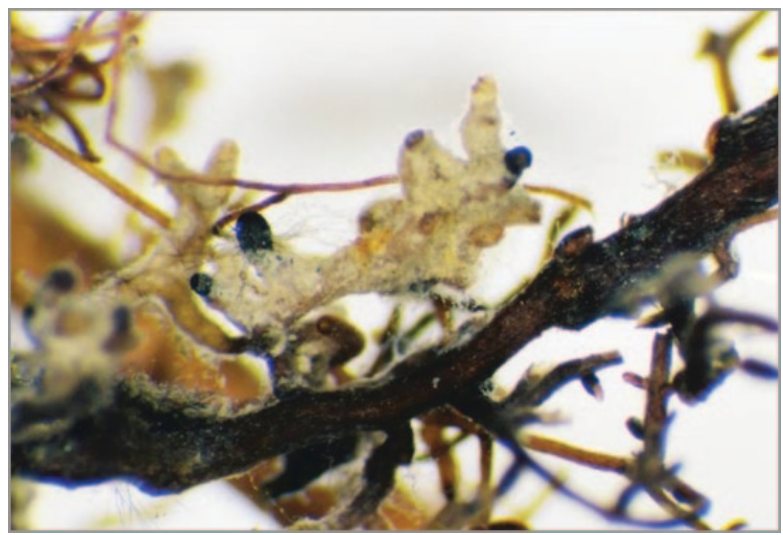

Slika 10 Različiti morfološki tipovi ektomikorize na korijenju hrasta lužnjaka (povećanje 10x) Figure 10 Different morphological ectomycorrhizal tips on pedunculate oak root (magnification 10x)

stanja staništa, te oštećenja i degradacije šumskih tala (Tikvić i sur., 2012).

Glavni ekološki problemi u staništima tartufa u Hrvatskoj su promjene vlažnosti šumskog tla (isušivanje i zamočvarenje), promjene dinamike oborina, promjene temperatura zraka, onečišćenje zraka, vode i šumskog tla, promjene mikroreljefa nizinskih šuma, promjene fizikalnih, kemijskih i bioloških obilježja šumskih tala, erozija šumskih tala i dr.

Zbog djelovanja nepovoljnih čimbenika dolazi do sve veće degradacije šumskih tala, što utječe na procese u tlu. Posljedice toga se nepovoljno odražavaju na stanje stabala i stanje mikorize na korijenju (slika 9).

U šumskom tlu žive desetci tisuća vrsta gljiva, a jedan gram površinskog dijela šumskog tla može sadržavati preko milijun propagila odnosno spora, fragmenata hifa i micelija u stanju mirovanja, te može biti razgranat nekoliko metara (slika 9 i 10). Na slici 9 prikazani su spletovi hifa na vrhu korjena uvećano 1500 puta (a) i spletovi micelija na korijenu uvećano 150 puta (b).

\section{Problemi potrajnog gospodarenja tartufima u Hrvatskoj - Problems of sustainable truffle management in Croatia}

Osnovno obilježje sadašnjeg načina gospodarenja tartufima u Hrvatskoj je neorganizirani pristup, koji dovodi do degradacije staništa te smanjenja količine i kakvoće tartufa. Prema Ćaleti (2001) iz godine u godinu se smanjuje količina i kvaliteta istarskih tartufa. Danas šumarski stručnjaci izdaju samo dozvole za sakupljanje tartufa i nemaju nadzor nad sakupljenim količinama tartufa u šumama, posebice ako se oni sakupljaju noću. Smanjenje količina tartufa, prekomjerno i nepravilno sakupljanje, nestručnost tartufara i nelegalna trgovina, kao i drugi nepovoljni čimbenici, predstavljaju glavne probleme u gospodarenju tartufima u Hrvatskoj. Preintenzivno i neorganizirano saku- pljanje tartufa, kao i stalno presijecanje korijenja šumskog drveća lopaticama za kopanje, uzrokuju degradaciju mikorize i smanjenje plodonošenja tartufa u šumama. Poremećaji prirodnog vodnog režima u nizinskim šumama, isušivanje i zamočvarenje šumskih staništa, dugotrajno zadržavanje poplavne i površineske vode uzrokuju intenzivno izvanredno odumiranje i smanjenje vitalnosti stabala hrasta lužnjaka i drugih vrsta drveća, što se nepovoljno odražava na razvoj mikorize i plodonošenje tartufa.

U novije vrijeme tartufi se sve više proizvode u plantažama u kojima se nastoje smanjiti nepovoljni čimbenici i unaprijediti ekološki uvjeti, kako bi proizvodnja plodišta tartufa bila što veća.

\section{RASPRAVA I ZAKLJUČCI DISCUSSION AND CONCLUSIONS}

Prirodna rasprostranjenost tartufa u Hrvatskoj se preklapa s prirodnom rasprostranjenošću vrsta šumskog drveća koje tvore simbiozu s tartufima. Tamo gdje postoje simbionati tartufa razvijaju se i tartufi. Veliki bijeli tartuf razvija se u nizinskim šumama, a različite vrste crnih tartufa od nizinskih do brdskih područja primorske i kontinentalne Hrvatske. Najbrojnija nalazišta tartufa u Hrvatskoj su u nizinskim i brežuljkastim područjima, dok su manje zastupljena nalazišta u brdskim područjima, iako su tartufi pronađeni i u brdskim bukovim šumama.

Sve se češće pojavljuju nepovoljni čimbenici koji utječu na stabilnost šumskih ekosustava, na šumsko drveće, šumsko tlo i mikroorganizme u tlu. Oni izazivaju poremećaje fizikalnih, kemijskih i bioloških obilježja šumskih tala, kao što su nedostatak kisika, nedostatak hranjiva, smanjuje poroznosti šumskog tla i smanjenje plinova u tlu. Zbijanje tla i odnošenje listinca može smanjiti zastupljenost ektomikoriznih gljiva i njihovu raznolikost za $60 \%$ (Wiensczyk i sur., 2002) 
Gospodarenje šumama treba obuhvaćati gospodarenje sa svim organizmima u šumama (pa i tartufima), ali i gospodarenje sa staništem, s obzirom na važnost optimalnih stanišnih uvjeta za razvoj šumskog drveća i drugih organizama. Potrajno gospodarenje šumama treba obuhvaćati i potrajno gospodarenja sa svim šumskim dobrima, pa i tartufima, te ga je potrebno uspostaviti.

\section{ZAHVALA}

\section{ACKNOWLEDGEMENT}

Autori se zahvaljuju Šumarskoj savjetodavnoj službi na potpori ovog istraživanja.

\section{LITERATURA}

\section{REFERENCES}

- Arnolds, E., 1991: Decline of ectomycorrhizal fungi in Europe, Agriculture, Ecosystems and Environment, 35:209-244.

- Bonito, G., Smith, M.E., Nowak, M., Healy, R.A., Guevara, G., Cazeres, E., Kinoshita, A., Nouhra, E.R., Doninguez, L.S., Tedersoo, L., Murat, C., Wang, Y., Arroyo Moreno, B., Pfister D. H., Nara, K., Zambonelli, A., Trappe, J.M., Vilgalys, R., 2013: Historical Biogeography and Diversification of Truffles in the Tuberaceae and Their Newly Identified Southern Hemisphere Sister Lineage. PloS ONE 8(1): e52765.

- Božac, R., 2008: Enciklopedija gljiva 2, Školska knjiga, str. 6 57, 686 - 700, Zagreb

- Bragato, G., Sladonja, B., Peršurić, Đ., 2004: The soil environment for Tuber magnatum growth in Motovun forest, Istria, Nat. Croat., Vol. 13, No 2: 171-185, Zagreb

- Ćaleta, M., 2001: Kako sačuvati tartufe i uvesti red među tartufare, Hrvatske šume, broj 61: 16 - 17, Zagreb
- Frančišović, S., 1950: Naši tartufi, Šumarski list, 1-2:23-38, Zagreb

- Hall, I.R., Brown, G.T., Zambonelli, A., 2007: Taming the truffle, The History, Lore, and Science of the Ultimate Mushroom, Timber press, str. 22-33, 55-57, 99-116, 214, Portland

- Hrka, J., 1984: Općenito o tartufima, njihovim nalazištima i uzgoju na umjetan način, Šumarski list, 11 - 12: 523 - 536., Zagreb

- Hrka, J., 1988: Tartufi. Mladost, str. 1-75, Zagreb

- Pravilnik o zaštiti gljiva, 2002, Narodne novine, 34/02.

- Smith, S. E., Read, D. J., 1997: Mycorrhizal Symbiosis, Academic Press, p. 1-605, San Diego

- Souch, C. A., Martin, P. J., Stephens, W., Spoor, G., 2004: Effects of soil compaction and mechanical damage at harvest on growth and biomass production of short rotation coppice willow. Plant and Soil 263, p. 173-182.

- Tikvić, I., Ugarković, D., Kobasić, Z., 2012: Ecophysiological Distrubances of Mycorrhiza Caused by the Application of Forest Operations in Forest Ecosystems - Review. Proceedings of 45th IUFRO International Symposium on Forestry mechanization. „Forest Engineering: Concern, Knowledge and Accountability in Today's Environment", str. 1-9, Zagreb.

- Wiensczyk A. M., Gamiet, S., Durall, D. M., Jones, M. D., Simard, S. W., 2002: Ectomycorrhizae and forestry in British Columbia: A summary of current research and conservation strategies, B. C. Journal of Ecosystems and Management, Vol. 2, No. $1: 1-20$

- Wilpert, K., Schäffer, J., 2006: Ecological effects of soil compaction and initial recovery dynamics: a preliminary study, European Journal of Forest Research, 125:129-138.

- Zgrablić, Ž., Brenko, A., Matočec, N., Kušan, I., Fornažar, A., Čulinović, J., Prekalj, G., 2014: Povijesni pregled poznavanja i gospodarenja tartufima, Strategija održivog tartufarstva u Istarskoj županiji, Istarska županija, Upravni odjel za poljoprivredu, šumarstvo, lovstvo, ribarstvo i vodoprivredu, str. 9-11, 22-27, Pazin

\section{Summary}

Truffles are natural symbiotic fungi on forest trees which develop in most forest ecosystems in Croatia. They draw special attention due to their gastronomic properties and high price. In Croatia truffles are most intensively collected in forests of Istria, even though they are known to exist also in other mediterranean and continental parts of Croatia up to $600 \mathrm{~m}$ above sea level. This paper presents new localities where truffles have been discovered in Croatia, as well as the data about truffle distribution in Europe. The truffle management in forest ecosystems of Croatia is not fully organized. The issues of sustainable truffle management in forests are the changing of ecological conditions, intensive and unorganized truffle collection and decrease of tree vitality. This paper discusses the most important unfavorable ecological and other factors for truffle development. Also, possibilities for improvement of truffle production in forests and truffle farms are presented, with special attention to habitat management.

KEY WORDS: truffles, new truffle locality, sustainable truffle management 